\title{
Desipramine induces apoptosis in hepatocellular carcinoma cells
}

\author{
DONG KWON YANG and SHANG-JIN KIM
}

\begin{abstract}
Department of Veterinary Pharmacology and Toxicology, College of Veterinary Medicine, Biosafety Research Institute and Korea Zoonosis Research Institute, Chonbuk National University, Iksan, Jeollabuk-do 54596, Republic of Korea
\end{abstract}

Received January 12, 2017; Accepted May 31, 2017

DOI: 10.3892/or.2017.5723

\begin{abstract}
Antitumor effects of antidepressants have been reported in many cancer cell lines. However, anti-proliferative effects of desipramine, a tricyclic antidepressant, in hepatocellular carcinoma are currently unknown. In this study, we examined the effects of desipramine in human hepatoma Hep3B cells. To evaluate anti-proliferative effects of desipramine in Hep3B cells, we determined cell viability, reactive oxygen species (ROS) production, mitochondrial membrane potential (MMP), mitogen-activated protein kinase (MAPK) activity, and intracellular $\mathrm{Ca}^{2+}$ levels after desipramine treatment. Desipramine reduced cell viability, increased ROS production, and decreased MMP activity in Hep3B cells. In addition, desipramine activated MAPKs (ERK 1/2, JNK, and p38) and increased intracellular $\mathrm{Ca}^{2+}$ levels. Pro-apoptotic effects of desipramine were abolished after MAPK inhibitors (PD98059, SB203580, and SP600125) or N-acetyl-L-cysteine (NAC), as a ROS scavenger, treatments. These findings suggest that desipramine shows anti-proliferative effects in Hep3B cells mediated by promotion of apoptosis, activation of MAPK signaling, and increase in intracellular $\mathrm{Ca}^{2+}$ levels.
\end{abstract}

\section{Introduction}

Hepatocellular carcinoma (HCC) is the fifth most common malignant tumor in the world, especially in Southeast Asia and Africa (1). Hepatitis B and C viral infections, chronic alcohol consumption and aflatoxin $\mathrm{B} 1$ exposure are predominant risk factors for HCC development (2). Although understanding of HCC pathogenesis and clinical therapies for HCC treatment have been achieved, HCC incidence and survival of HCC patients are still unsatisfactory (3). Therefore, effective prognostic indicators and therapeutic strategy for HCC are needed.

Correspondence to: Dr Shang-Jin Kim, Department of Veterinary Pharmacology and Toxicology, College of Veterinary Medicine, Chonbuk National University, Iksan Campus, 79 Gobong-ro, Iksan-si, Jeollabuk-do 54596, Republic of Korea

E-mail: abbasj@jbnu.ac.kr

Key words: desipramine, antidepressants, hepatocellular carcinoma, apoptosis, Hep3B cells
Antidepressants are clinically prescribed to cancer patients for the treatment of various disorders, including depression, psychiatric disorders, and chronic pain $(4,5)$. In addition, antidepressant drugs reduce hot flashes in patients treated with chemotherapy and protect normal cells from radiation and chemotherapy (6). Antitumor effects of selective serotonin (SSRIs) and serotonin and norepinephrine reuptake inhibitors (SNRIs) have been reported in several cancer cell lines. Fluoxetine, an SSRI antidepressant, was shown to inhibit the growth of tumor-derived cell lines by promoting apoptosis through activation of MAPK and caspase-3 pathways in human carcinoma, osteosarcoma, glioma, and hepatocellular carcinoma cells (7-9). Recently, SNRIs, duloxetine and milnacipran, were shown to damage HepG2 cells (10).

Tricyclic antidepressants (TCAs), including desipramine are an alternative to SSRIs. They are first-line drugs for pharmacological treatment of neuropathic pain (11). Therapeutic effect of desipramine is attributed to inhibition of norepinephrine reuptake (12). TCAs have been reported to reduce the viability of various cell lines $(13,14)$ and induce neurotoxicity associated with Parkinson's disease (15). However, potential antitumor effects of desipramine on hepatocellular carcinoma cells have not been explored and are the focus of this study.

\section{Materials and methods}

Cell culture and reagents. Hep3B cells were obtained from the Korea Cell Line Bank (KCLB, Seoul, Korea) and grown in Dulbecco's modified Eagle's medium nutrient mixture F-12 HAM (DMEM F-12 HAM) supplemented with $10 \%$ fetal bovine serum, $1 \%$ antibiotics, $5 \mathrm{mM}$ L-glutamine. Desipramine, 4',6-diamidino-2-phenylindole (DAPI) and 5,5',6,6'-tetrachloro-1,1',3,3'-tetraethyl benzimidazolyl-carbocyanine iodide (JC-1) was purchased from Enzo Life Sciences (Plymouth Meeting, PA, USA). 2',7'-Dichlorodihydrofluorescin diacetate (DCFH-DA) was purchased from Thermo Fisher Scientific (Waltham, MA, USA).

Cell viability assay. Cell viability assay was measured by using Cell Counting Kit-8 (CCK-8; Enzo Life Sciences). Briefly, Hep3B cells were seeded into 96-well plates (5000 cells/well) and cultured for $24 \mathrm{~h}$ in DMEM F-12 HAM containing $10 \%$ fatal bovine serum. After treatment of desipramine $(30-500 \mu \mathrm{M})$ for $24 \mathrm{~h}$, the CCK-8 reagent was added to each well, and the cells were incubated at $37^{\circ} \mathrm{C}$ for an additional $2 \mathrm{~h}$. Absorbance was measured at $450 \mathrm{~nm}$ using 

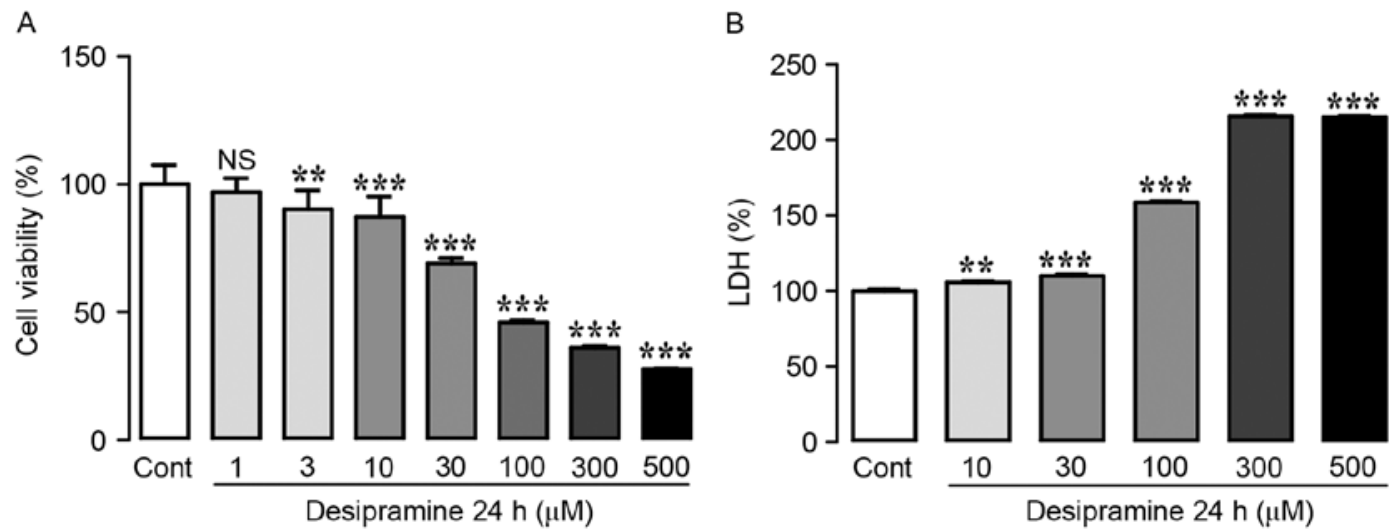

Figure 1. Effects of desipramine on cell viability and LDH release in Hep3B cells. CCK-8 and LDH assay were performed after $24 \mathrm{~h}$ desipramine treatment of Hep3B cells. (A) Effects of desipramine on viability of Hep3B cells after $24 \mathrm{~h}$ desipramine treatment (1-500 $\mu \mathrm{M})$. (B) LDH release was determined after $24 \mathrm{~h}$ desipramine treatment $(10-500 \mu \mathrm{M})$. Data are expressed as \% changes \pm SEM vs. the control group. Differences between the groups were analyzed using a one-way ANOVA followed by Bonferroni's post-hoc test. ${ }^{* *} \mathrm{P}<0.01,{ }^{* * *} \mathrm{P}<0.001$ vs. control. Cont, control; LDH, lactic dehydrogenase; NS, not significant.

A

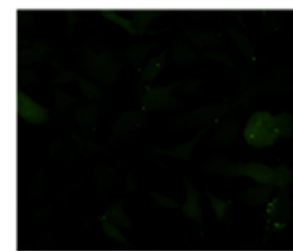

Cont

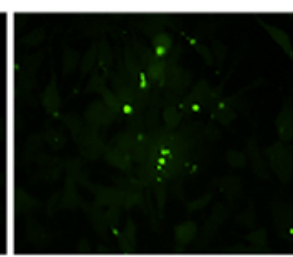

Desi $3 \mu \mathrm{M}$

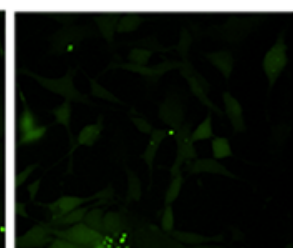

Desi $10 \mu \mathrm{M}$

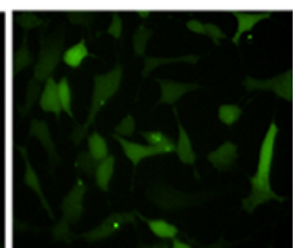

Desi $30 \mu \mathrm{M}$

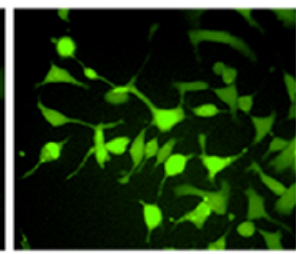

Desi $100 \mu \mathrm{M}$
B

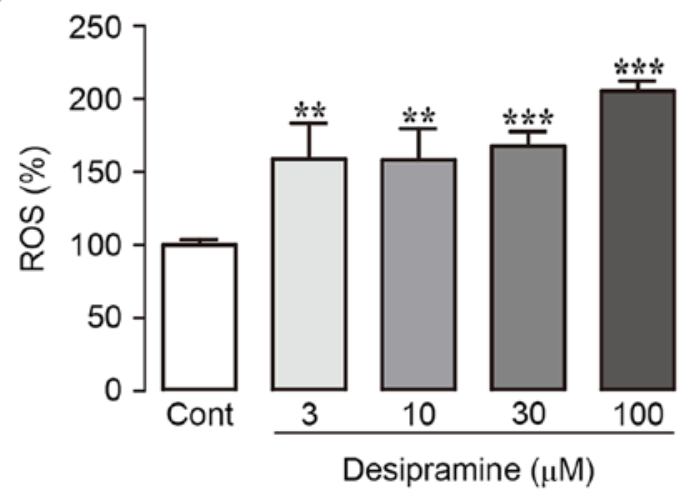

C

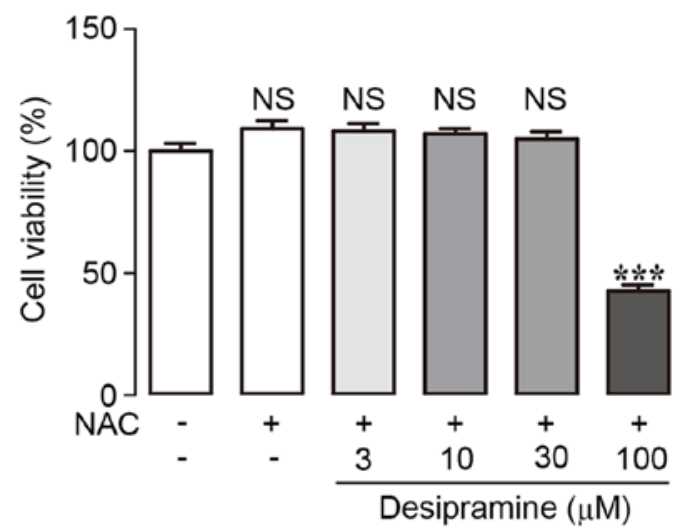

Figure 2. Effects of desipramine on ROS production in Hep3B cells. ROS production was determined by incubating desipramine-treated cells with DCFH-DA dye for $30 \mathrm{~min}$. (A) Representative image of desipramine-treated Hep3B cells after $24 \mathrm{~h}$. (B) Fluorescence intensity determined using spectrophotometry. (C) Cell viability was analyzed after $24 \mathrm{~h} 10 \mathrm{mM}$ NAC treatment in the presence of desipramine (3-100 $\mu \mathrm{M})$. Data are expressed as $\%$ changes \pm SEM vs. the control group. . Differences between the groups were analyzed using a one-way ANOVA followed by Bonferroni's post-hoc test. ${ }^{* *} \mathrm{P}<0.01,{ }^{* * * *} \mathrm{P}<0.001$ vs. control. Cont, control; Desi, desipramine; NS, not significant.

a spectrophotometer (Spectra Max M5; Molecular Devices, Sunnyvale, CA, USA). For the treatment of N-acetylcysteine (NAC), cells were treated with desipramine (3-100 $\mu \mathrm{M})$ with or without $10 \mathrm{mM} \mathrm{NAC}$ for $24 \mathrm{~h}$. Cells were then applied to CCK-8 assay for cell viability assay.

LDH (lactic dehydrogenase) activity measurement. LDH activity was measured by a chemical colorimetric method using cytotoxic detection kit (Takara Bio Inc., Shinga, Japan). Briefly, after $48 \mathrm{~h}$ incubation of the Hep3B cells in 12-well plates $\left(1 \times 10^{4}\right.$ cells/well), the cells were treated with desipramine
$(10-500 \mu \mathrm{M})$. After $24 \mathrm{~h}$ incubation, culture media were collected and centrifuged at $10,000 \mathrm{xg}$ for $10 \mathrm{~min}$. Optical density values were measured at $490 \mathrm{~nm}$ using a spectrophotometer (Spectra Max M5; Molecular Devices).

Measurement of intracellular reactive oxygen species (ROS) production. Intracellular ROS can oxidize the non-fluorescent DCF to the highly fluorescent DCF. Thus, intracellular ROS can be measured by fluorescence intensity of DCF by a fluorometer. Briefly, after $48 \mathrm{~h}$ incubation of Hep3B cells in 12 -well plates $\left(1 \times 10^{4}\right.$ cells/well), cells were treated with 
A
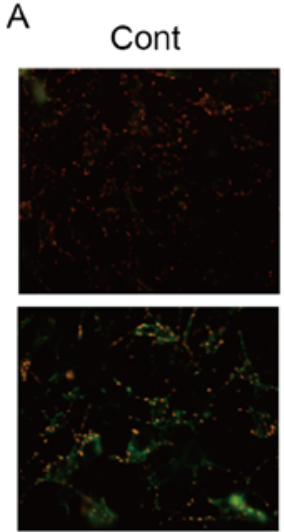

Desi $10 \mu \mathrm{M}$

B

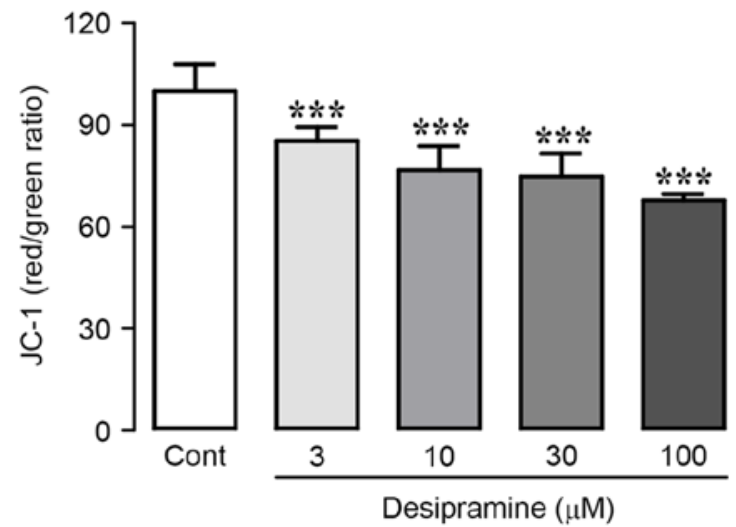

Figure 3. Effects of desipramine on MMP in Hep3B cells. MMP was determined in desipramine-treated cells with JC-1 dye for $10 \mathrm{~min}$. (A) Representative image of Hep3B cells stained with JC-1 dye (10 mg/ml, $10 \mathrm{~min})$ after $24 \mathrm{~h}$ desipramine treatment $(3-100 \mu \mathrm{M})$, observed under a fluorescence microscope. (B) JC-1 fluorescence was measured using a spectrophotometer at $550 \mathrm{~nm}$ excitation/600 $\mathrm{nm}$ emission and $485 \mathrm{~nm}$ excitation/535 nm emission wavelengths for red and green fluorescence, respectively. Data are expressed as means \pm SEM. Differences between the groups were analyzed using a one-way ANOVA followed by Bonferroni's post-hoc test. ${ }^{* * *} \mathrm{P}<0.001$ vs. control. Cont, control; Desi, desipramine; NS, not significant.

desipramine $(3-100 \mu \mathrm{M})$ for $24 \mathrm{~h}$. Hep3B cells were then treated with $10 \mu \mathrm{M}$ DCFH-DA for $30 \mathrm{~min}$ at $37^{\circ} \mathrm{C}$. Cells were observed under a fluorescence microscope (IX-81; Olympus Corp.). Fluorescence intensity was calculated using a spectrophotometer at excitation and emission wavelengths of 488 and $515 \mathrm{~nm}$, respectively.

MMP (mitochondrial transmembrane potential) assessment by JC-1 staining. After $48 \mathrm{~h}$ incubation of Hep3B cells in 12 -well plates $\left(1 \times 10^{4}\right.$ cells/well $)$, cells were treated with desipramine $(3-100 \mu \mathrm{M})$ for $24 \mathrm{~h}$. Cells were then incubated with $10 \mu \mathrm{g} / \mathrm{ml} \mathrm{JC}-1$ for $10 \mathrm{~min}$. JC-1-labelled cells were observed under a fluorescence microscope (IX-81; Olympus Corp.). JC-1 fluorescence was measured using spectrophotometer with $550 \mathrm{~nm}$ excitation/600 $\mathrm{nm}$ emission for red fluorescence and $485 \mathrm{~nm}$ excitation/535 $\mathrm{nm}$ emission wavelengths for green fluorescence.

Western blot analysis of MAPKs. Hep3B cells were treated with desipramine $(100 \mu \mathrm{M})$ at each time point $(1,2,4$, and
$8 \mathrm{~h}$, respectively). In addition, cells were treated with desipramine (3-10 $\mu \mathrm{M})$ with/without pre-incubation of MAPK inhibitors (PD98059, SB203580, and SP600125) for $24 \mathrm{~h}$. Cells were harvested and lysed in RIPA buffer containing protease inhibitor cocktail (Roche, Indianapolis, IN, USA). Protein homogenates were separated on SDS-PAGE gels and transferred to PVDF membranes (Bio-Rad, Hercules, CA, USA). After blocking for $1 \mathrm{~h}$ with $5 \%$ non-fat dry milk, the membranes were incubated overnight at $4{ }^{\circ} \mathrm{C}$ with antibodies against total or phosphorylated extracellular signal-regulated kinase 1/2 (ERK1/2), c-JUN N-terminal kinase (JNK), p38, or $\beta$-actin (Cell Signaling Technology, Danvers, MA, USA). Next, the membranes were incubated with the appropriate HRP-conjugated secondary antibodies (Cell Signaling Technology) for $1 \mathrm{~h}$ and the bands were detected using enhanced chemiluminescence. The blots were scanned by a Bio-Rad ChemiDoc XRS and the intensity of each protein was quantified by Quantity One 4.5.0 software (Bio-Rad).

$\mathrm{Ca}^{2+}$ measurement. Intracellular $\mathrm{Ca}^{2+}$ concentration was measured by using the fluorescent dye, Fura-2/AM (Thermo Fisher Scientific). Hep3B cells were incubated in 6-well plates $\left(1 \times 10^{4}\right.$ cells/well) on laminin-coated coverglass. Cells were then washed with the HEPES-TRIS buffer, and loaded with $5 \mu \mathrm{M}$ Fura-2/AM, together with $0.025 \%$ pluronic F127 (Thermo Fisher Scientific) for $30 \mathrm{~min}$. The fluorescence was monitored under a fluorescence microscope (IX-81; Olympus Corp.) with 340 and $380 \mathrm{~nm}$ excitation/510 nm emission wavelengths. The equation $\left[\mathrm{Ca}^{2+}\right]=\left(\mathrm{R}-\mathrm{R}_{\min }\right) /\left(\mathrm{R}_{\max }-\mathrm{R}\right) \mathrm{Sf} \times \mathrm{Kd}$ was used to convert the Fura-2/AM ratios to intracellular concentrations. $\mathrm{R}$ is the Fluo-3/AM 340/380 ratio.

Statistical analysis. The data are reported as the mean \pm SEM. Statistical significance was analyzed by using one-way analysis of variance (ANOVA) with Bonferroni's post-hoc test (Prism 5.0.3, GraphPad Software Inc., San Diego, CA, USA). P<0.05 was considered to indicate a statistically significant difference.

\section{Results}

Effects of desipramine on cell viability of Hep3B cells. In order to determine the anti-proliferative potential of desipramine in hepatocellular carcinoma cells, viability of Hep3B cells was investigated using the CCK-8 assay after treatment with 1, 3, $10,30,100,300$, and $500 \mu \mathrm{M}$ desipramine for $24 \mathrm{~h}$. As shown in Fig. 1A, desipramine induced cell death in a dose-dependent manner. Treatment of Hep3B cells with $1 \mu \mathrm{M}$ desipramine did not affect cell viability, whereas 3-500 $\mu \mathrm{M}$ desipramine induced a significant decrease in cell viability $(90.2 \pm 2.9$, $87.4 \pm 3.0,69.1 \pm 2.1,45.9 \pm 1.1,36.1 \pm 0.7$, and $27.8 \pm 0.2 \%$ at 3 , $10,30,100,300$, and $500 \mu \mathrm{M}$, vs. control cells, respectively) (Fig. 1A). As LDH is used as an indicator of cytotoxicity because of $\mathrm{LDH}$ release upon loss of cell membrane integrity, we also determined LDH activity after desipramine treatment $(10-500 \mu \mathrm{M})$. Desipramine treatment markedly increased LDH activity in a dose-dependent manner $(105.7 \pm 0.8,109.8 \pm 1.1$, $150.3 \pm 8.4,227.7 \pm 12.1$, and $255.7 \pm 40.7 \%$ at $10,30,100,300$, and $500 \mu \mathrm{M}$, vs. control cells, respectively). Collectively, these results demonstrate that desipramine inhibits the proliferation of Hep3B cells (Fig. 1B). 
A
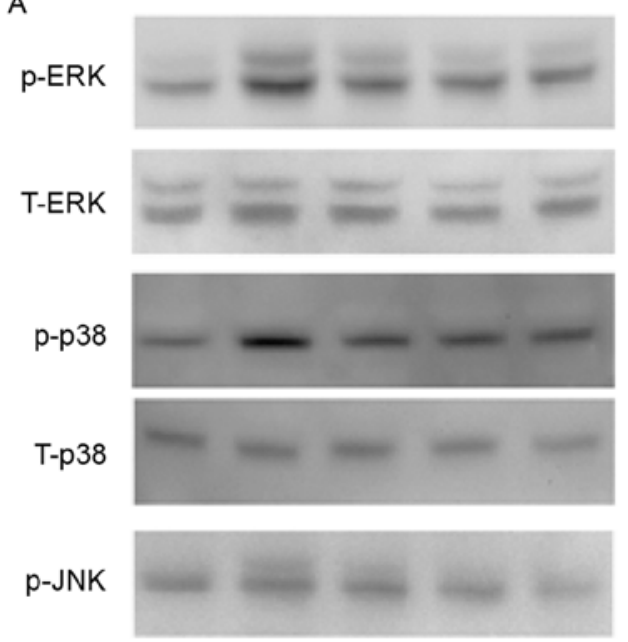

T-JNK

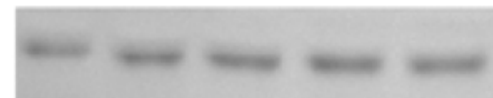

$\beta$-actin

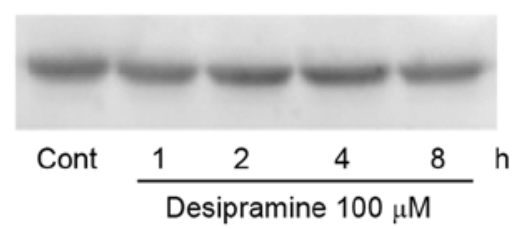

B

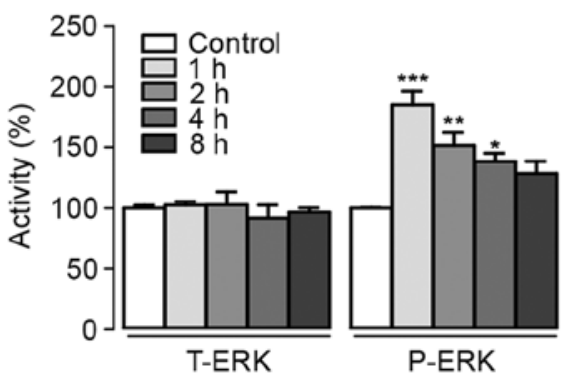

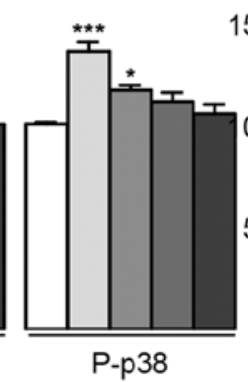

]$\left._{0}^{150}\right]^{1}$

T-JNK

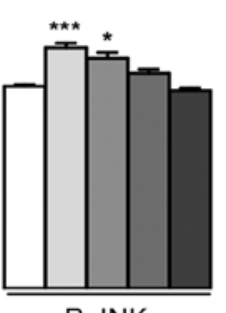

P-JNK

C

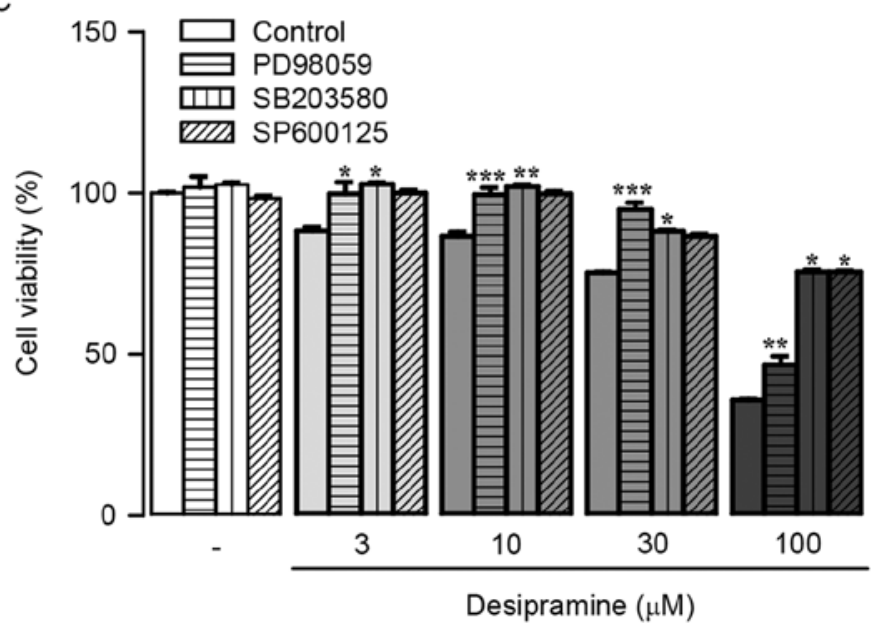

Figure 4. Effects of desipramine on MAPK protein expression in Hep3B cells. (A) Cell extracts from desipramine-treated Hep3B cells at different time points $(1,2,4$, and $8 \mathrm{~h}$, respectively) were analyzed using western blotting. (B) Total and phosphorylated forms of ERK1/2, p38, and JNK were quantified with scanning densitometry. $\beta$-actin was used as the loading control. (C) The cells were pre-incubated with MAPK inhibitors (PD98059, SB203580, and SP600125) followed by desipramine (3-100 $\mu \mathrm{M})$ treatments. Cell viability was determined using the CCK- 8 assay. Data are expressed as $\%$ changes \pm SEM vs. the control group. Differences between the groups were analyzed using a one-way ANOVA followed by Bonferroni's post-hoc test. ${ }^{*} \mathrm{P}<0.05,{ }^{* * *} \mathrm{P}<0.01,{ }^{* * * *} \mathrm{P}<0.001$ vs. control. Cont, control.

Effects of desipramine on ROS production in Hep3B cells. As ROS production activates pro-apoptotic signaling pathways, we analyzed the involvement of ROS in desipramine-induced apoptosis in Hep3B cells. ROS levels were assessed using DCFH-DA. Desipramine treatment significantly increased intracellular ROS generation in a dose-dependent manner $(158.8 \pm 10.5,158.1 \pm 15.7,167.6 \pm 3.8$, and $205.3 \pm 7.6 \%$ at 3,10 , 30 , and $100 \mu \mathrm{M}$ vs. control cells, respectively) (Fig. 2A and B). In addition, treatment with the ROS scavenger NAC $(10 \mathrm{mM})$ significantly attenuated desipramine-induced cell death, according to the CCK-8 assay (Fig. 2C).
Effects of desipramine on MMP in Hep3B cells. In order to analyze mitochondrial activity in the presence of desipramine, we observed the effect of desipramine on MMP using JC-1, an MMP-sensing dye. During apoptosis, mitochondrial depolarization occurs, altering the fluorescence of JC-1 from red (aggregates) to green (monomers). Desipramine significantly reduced MMP in Hep3B cells in a dose-dependent manner, indicated by a shift from red to green JC-1 fluorescence (Fig. 3A). To corroborate these results, we monitored the fluorescence intensity of JC-1 using spectrophotometry. As concentration of desipramine increased, the ratio of red/green 
A

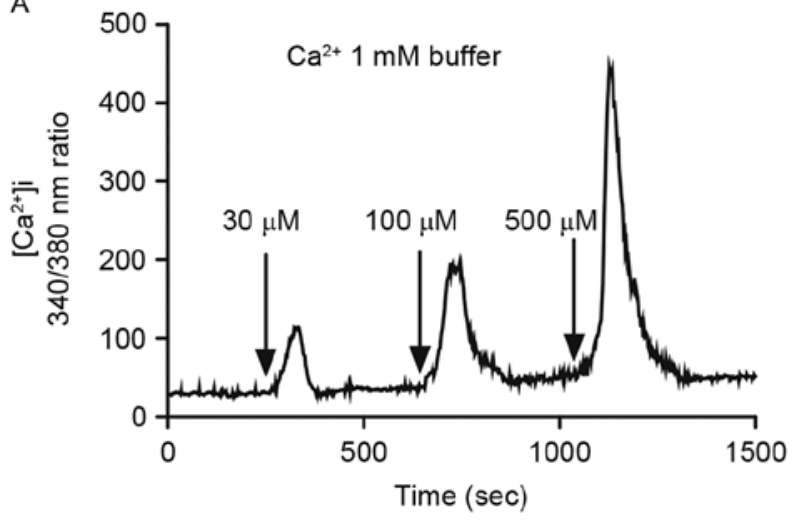

B

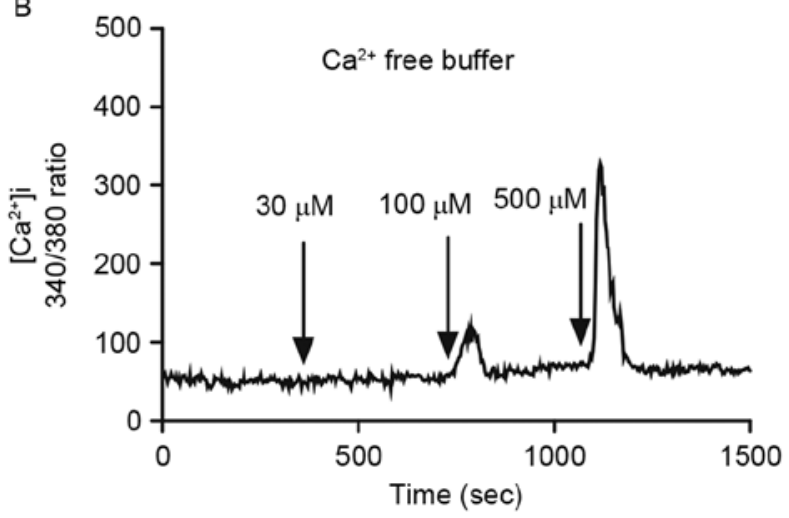

Figure 5. Effects of desipramine on $\left[\mathrm{Ca}^{2+}\right]$ i. Hep3B cells in $1 \mathrm{mM} \mathrm{Ca}^{2+}(\mathrm{A})$ or $\mathrm{Ca}^{2+}$-free buffer (B) were treated with desipramine $(30-500 \mu \mathrm{M})$ at indicated time points, and loaded with Fluo-3/AM for $30 \mathrm{~min}$. Fluorescence intensity was determined at 340 and $380 \mathrm{~nm}$.

fluorescence intensity markedly decreased $(85.4 \pm 1.2,76.6 \pm 2.9$, $74.8 \pm 2.0$, and $67.9 \pm 1.7 \%$ at $3,10,30$, and $100 \mu \mathrm{M}$ vs. control cells, respectively) (Fig. 3B).

Effect of desipramine on the MAPK signaling in Hep $3 B$ cells. In order to identify molecular mechanisms underlying anti-proliferative effects of desipramine in Hep3B cells, we determined protein expression patterns of MAPKs (ERK1/2, JNK, and p38) involved in pro-apoptotic signaling pathways. Results showed that phospho-ERK levels were significantly increased after $100 \mu \mathrm{M}$ desipramine treatment for 1,2 , and $4 \mathrm{~h}$ compared with control cells $(185.2 \pm 10.1,151.5 \pm 9.8$, and $138.5 \pm 6.1 \%$ at 1,2 , and $4 \mathrm{~h}$ vs. control cells, respectively). In addition, phospho-p38 and JNK expression levels were significantly increased after $100 \mu \mathrm{M}$ desipramine treatment for 1 and $2 \mathrm{~h}$ compared with control cells $(135.1 \pm 4.8$ and $116.4 \pm 2.3 \%$ increase in p-38, 118.9 \pm 2.3 and $113.9 \pm 2.8 \%$ increase in p-JNK vs. control cells, respectively) (Fig. 4A and B). Pre-incubation with $20 \mu \mathrm{M}$ PD98059 (ERK1/2 inhibitor), SB203580 (p38 inhibitor), or SP600125 (JNK inhibitor) followed by exposure to desipramine $(3-100 \mu \mathrm{M})$ revealed that all three inhibitors abolished the anti-proliferative effect of desipramine in Hep3B cells (Fig. 4C).

Effects of desipramine on $\left[\mathrm{Ca}^{2+}\right] \mathrm{i}$ in Hep3B cells. Since abnormal $\left[\mathrm{Ca}^{2+}\right]$ i rise may lead to interruption of ion flux, protein dysfunctions, or apoptosis (16), we analyzed $\left[\mathrm{Ca}^{2+}\right] \mathrm{i}$ after desipramine treatment $(30,100$, and $500 \mu \mathrm{M})$ in $\mathrm{Ca}^{2+}$-free or $1 \mathrm{mM}$ $\mathrm{Ca}^{2+}$-buffer using Fura-2/AM, a fluorescent $\mathrm{Ca}^{2+}$-sensitive dye. Desipramine induced $\left[\mathrm{Ca}^{2+}\right] \mathrm{i}$ increase in a concentrationdependent manner in $1 \mathrm{mM} \mathrm{Ca}{ }^{2+}$-containing buffer (Fig. 5A). Similarly, $\left[\mathrm{Ca}^{2+}\right] \mathrm{i}$ increase occurred after 100 and $500 \mu \mathrm{M}$ desipramine treatment in $\mathrm{Ca}^{2+}$-free buffer (Fig. 5B).

\section{Discussion}

In the present study, we demonstrated that desipramine inhibits proliferation of Hep3B cells by inducing apoptosis, which suggests the antitumor potential of this drug in hepatocellular carcinoma. Some antidepressants (e.g., paroxetine, fluvoxamine and sertraline) have potent anticancer properties against various cancer cell lines $(17,18)$. In contrast, these drugs were also reported to stimulate or not affect proliferation of tumor cells $(19,20)$. Cytotoxic effects of desipramine were demonstrated in several cancer cell lines, including prostate cancer, colon, renal tubular, and glioma cells (21-23). Consistent with previous observations, we found that viability of Hep3B cells was decreased after desipramine treatment in a dose-dependent manner (Fig. 1A). Furthermore, increased $\mathrm{LDH}$ release confirmed the cell damage caused by desipramine (Fig. 1B).

ROS play an important role in oxidative stress, which is primarily generated in mitochondria. In tumor cells, increased ROS generation promotes proliferation, altered metabolism, and angiogenesis, and is controlled by the oxidant/anti-oxidant balance system (24). When this system is impaired, excessive amounts of ROS eventually lead to tumor cell death. Our results demonstrated that desipramine treatment markedly induced ROS production in Hep3B cells, an effect prevented by treatment with NAC, a ROS scavenger (Fig. 2). In addition, desipramine decreased MMP in Hep3B cells (Fig. 3). Overproduction of ROS causes mitochondria damage, loss of MMP, and eventually, apoptosis via mitochondria-mediated cell death pathway (25).

MAPK signaling pathways are known regulators of cell survival, proliferation, and stress response and are responsible for the apoptotic cascade in a number of cancer cell lines. Many anticancer agents activate MAPK pathways in various cell types (26). We examined the effects of desipramine on the expression of three major MAPK proteins (ERK1/2, JNK, and p38) in Hep3B cells. Our results suggest that desipramine significantly inhibits the phosphorylation of ERK1/2, JNK, and p38. Furthermore, exposure to MAPK inhibitors suppressed desipramine-induced cell death (Fig. 4). These results indicate that MAPK signaling pathways play an important role in desipramine-induced cell death in Hep3B cells.

Intracellular $\mathrm{Ca}^{2+}$ is closely linked to ROS production with accumulation leading to apoptotic cell death (27). $\mathrm{Ca}^{2+}$ overload triggers the opening of the permeability transition pore, which is associated with mitochondrial cell death pathways of apoptosis (28). Increase in intracellular $\mathrm{Ca}^{2+}$ has been associated with apoptosis in tumor cells $(9,29)$. In this study, $\left[\mathrm{Ca}^{2+}\right] \mathrm{i}$ increased in response to desipramine treatment in $\mathrm{Ca}^{2+}$-free and $1 \mathrm{mM} \mathrm{Ca}^{2+}$ buffer (Fig. 5). These results indicate that 
desipramine causes $\mathrm{Ca}^{2+}$ influx or release of $\mathrm{Ca}^{2+}$ from endoplasmic reticulum. Consequently, increase in intracellular $\mathrm{Ca}^{2+}$ participates in desipramine-induced apoptosis of Hep3B cells.

In conclusion, the current study provides new evidence that desipramine induces apoptosis of hepatocellular carcinoma cells by increasing ROS production, reducing MMP, promoting accumulation of intracellular $\mathrm{Ca}^{2+}$, and increasing the activity of MAPK proteins (ERK1/2, JNK, and p38). We further propose desipramine as a potential anticancer agent against HCC.

\section{Acknowledgements}

This study was supported by the research funds of Korean Ministry of Science (2011-0013872) and the National Research Foundation of Korea (NRF) grant funded by the Korea government (MSIP) (2016R1A2B1010904).

\section{References}

1. Paul SB, Shalimar, Sreenivas V, Gamanagatti SR, Sharma H, Dhamija E and Acharya SK: Incidence and risk factors of hepatocellular carcinoma in patients with hepatic venous outflow tract obstruction. Aliment Pharmacol Ther 41: 961-971, 2015.

2. El-Serag HB and Rudolph KL: Hepatocellular carcinoma: Epidemiology and molecular carcinogenesis. Gastroenterology 132: 2557-2576, 2007.

3. Kang TW and Rhim H: Recent advances in tumor ablation for hepatocellular carcinoma. Liver Cancer 4: 176-187, 2015.

4. Riblet N, Larson R, Watts BV and Holtzheimer P: Reevaluating the role of antidepressants in cancer-related depression: A systematic review and meta-analysis. Gen Hosp Psychiatry 36: 466-473, 2014.

5. Smith EM, Pang H, Cirrincione C, Fleishman S, Paskett ED, Ahles T, Bressler LR, Fadul CE, Knox C, Le-Lindqwister N, et al; Alliance for Clinical Trials in Oncology: Effect of duloxetine on pain, function, and quality of life among patients with chemotherapy-induced painful peripheral neuropathy: A randomized clinical trial. JAMA 309: 1359-1367, 2013.

6. Lieb J: Antidepressants, prostaglandins and the prevention and treatment of cancer. Med Hypotheses 69: 684-689, 2007.

7. Chou CT, He S and Jan CR: Paroxetine-induced apoptosis in human osteosarcoma cells: Activation of p38 MAP kinase and caspase-3 pathways without involvement of $\left[\mathrm{Ca}^{2+}\right]$ i elevation. Toxicol Appl Pharmacol 218: 265-273, 2007.

8. Stepulak A, Rzeski W, Sifringer M, Brocke K, Gratopp A, Kupisz K, Turski L and Ikonomidou C: Fluoxetine inhibits the extracellular signal regulated kinase pathway and suppresses growth of cancer cells. Cancer Biol Ther 7: 1685-1693, 2008.

9. Mun AR, Lee SJ, Kim GB, Kang HS, Kim JS and Kim SJ: Fluoxetine-induced apoptosis in hepatocellular carcinoma cells Anticancer Res 33: 3691-3697, 2013.

10. Kuwahara J, Yamada T, Egashira N, Ueda M, Zukeyama N, Ushio S and Masuda S: Comparison of the anti-tumor effects of selective serotonin reuptake inhibitors as well as serotonin and norepinephrine reuptake inhibitors in human hepatocellular carcinoma cells. Biol Pharm Bull 38: 1410-1414, 2015.

11. Finnerup NB, Attal N, Haroutounian S, McNicol E, Baron R, Dworkin RH, Gilron I, Haanpää M, Hansson P, Jensen TS, et al: Pharmacotherapy for neuropathic pain in adults: A systematic review and meta-analysis. Lancet Neurol 14: 162-173, 2015.
12. Dharmshaktu P, Tayal V and Kalra BS: Efficacy of antidepressants as analgesics: A review. J Clin Pharmacol 52: 6-17, 2012.

13. Haller I,Lirk P,KellerC, Wang GK, Gerner P and KlimaschewskiL: Differential neurotoxicity of tricyclic antidepressants and novel derivatives in vitro in a dorsal root ganglion cell culture model. Eur J Anaesthesiol 24: 702-708, 2007.

14. Kitagawa N, Oda M, Nobutaka I, Satoh H, Totoki T and Morimoto M: A proposed mechanism for amitriptyline neurotoxicity based on its detergent nature. Toxicol Appl Pharmacol 217: 100-106, 2006.

15. Lee MY, Hong S, Kim N, Shin KS and Kang SJ: Tricyclic antidepressants amitriptyline and desipramine induced neurotoxicity associated with Parkinson's disease. Mol Cells 38: 734-740, 2015.

16. Clapham DE: Intracellular calcium. Replenishing the stores. Nature 375: 634-635, 1995.

17. Bielecka AM and Obuchowicz E: Antidepressant drugs as a complementary therapeutic strategy in cancer. Exp Biol Med (Maywood) 238: 849-858, 2013.

18. Kubera M, Grygier B, Arteta B, Urbańska K, Basta-Kaim A Budziszewska B, Leśkiewicz M, Kołaczkowska E, Maes M, Szczepanik M, et al: Age-dependent stimulatory effect of desipramine and fluoxetine pretreatment on metastasis formation by B16F10 melanoma in male C57BL/6 mice. Pharmacol Rep 61: 1113-1126, 2009.

19. Volpe DA, Ellison CD, Parchment RE, Grieshaber CK and Faustino PJ: Effects of amitriptyline and fluoxetine upon the in vitro proliferation of tumor cell lines. J Exp Ther Oncol 3: $169-184,2003$

20. Li YF and Luo ZP: Desipramine antagonized corticosteroneinduced apoptosis in cultured PC12 cells. Acta Pharmacol Sin 23: 311-314, 2002.

21. Qi H, Chen HZ and Jin ZJ: Caspase 3 gene expression and $\left[\mathrm{Ca}^{2+}\right]$ i homeostasis underlying desipramine-induced C6 glioma cell apoptosis. Acta Pharmacol Sin 23: 803-807, 2002.

22. Ho CM, Kuo SY, Chen CH, Huang JK and Jan CR: Effect of desipramine on $\mathrm{Ca}^{2+}$ levels and growth in renal tubular cells. Cell Signal 17: 837-845, 2005.

23. Chang HC, Huang CC, Huang CJ, Cheng JS, Liu SI, Tsai JY, Chang HT, Huang JK, Chou CT and Jan CR: Desipramineinduced apoptosis in human PC3 prostate cancer cells: Activation of JNK kinase and caspase-3 pathways and a protective role of $\left[\mathrm{Ca}^{2+}\right]$ i elevation. Toxicology 250: 9-14, 2008.

24. Ríos-Arrabal S, Artacho-Cordón F, León J, Román-Marinetto E, Del Mar Salinas-Asensio M, Calvente I and Núñez MI: Involvement of free radicals in breast cancer. Springerplus 2: 404, 2013.

25. Estaquier J, Vallette F, Vayssiere JL and Mignotte B: The mitochondrial pathways of apoptosis. Adv Exp Med Biol 942: 157-183, 2012.

26. Chang HL, Wu YC, Su JH, Yeh YT and Yuan SS: Protoapigenone, a novel flavonoid, induces apoptosis in human prostate cancer cells through activation of p38 mitogen-activated protein kinase and c-Jun NH2-terminal kinase 1/2. J Pharmacol Exp Ther 325: 841-849, 2008

27. Perrone GG, Tan SX and Dawes IW: Reactive oxygen species and yeast apoptosis. Biochim Biophys Acta 1783: 1354-1368, 2008.

28. Orrenius S, Zhivotovsky B and Nicotera P: Regulation of cell death: The calcium-apoptosis link. Nat Rev Mol Cell Biol 4: $552-565,2003$.

29. Kim TH, Kim JS, Kim ZH, Huang RB, Chae YL and Wang RS: Induction of apoptosis in MCF-7 human breast cancer cells by Khz (fusion of Ganoderma lucidum and Polyporus umbellatus mycelium). Mol Med Rep 13: 1243-1249, 2016. 